TETIANA KUPRII,

Borys Grinchenko Kyiv University (Kyiv, Ukraine)

e-mail:t.kuprii@kubg.edu.ua,ORCID0000-0002-7305-5411

LIDIIA TYMISH,

Drohobych Ivan Franko State Pedagogical University (Drohobych, Ukraine)

e-mail: lidatymish21@gmail.com,ORCID 0000-0002-2142-8917

LEONID PANASIUK,

Borys Grinchenko Kyiv University (Kyiv, Ukraine)

e-mail: panlev@ukr.net,ORCID0000-0003-4216-8808

\title{
SUBCARPATHIAN RUTHENIA IN CONDITIONS OF PRE-WAR INTERNATIONAL CRISIS OF 1938 AND TERRITORIAL ENCROACHMENTS OF NEIGHBORING STATES (ON REGIONAL PRESS MATERIALS)
}

\begin{abstract}
Through the prism of the Subcarpathian press of the first third of the twentieth century, the tragic period of establishment of the Ukrainian statehood on the eve of World War II, the struggle for the free development of the Ukrainian nation on the territory of Subcarpathian Ruthenia due to the Munich Agreement and the dangerous political game of England, France, Germany and Italy, as well as Poland and Hungary, in the epicenter of ambitions of which Transcarpathia was caught, is delineated. Further development was given to the issues of struggle of the Ukrainians in Transcarpathia for the realization of the "peoples' right to self-determination" in the course of the forceful formation of the joint Polish-Hungarian border after the Second Czechoslovak crisis of 1938, which had given rise to the actual division of Czechoslovakia on the one hand, and the intensification of Ukrainians' national aspirations - on the other. The geopolitical aspects of the game of the Central Powers, as well as of Poland and Hungary in the process of "redrawing Europe", the international peculiarities of the policy of appeasement of an aggressor of 1938 as a process of concessions and losses, in which the Transcarpathian lands remained as currency and the government of the autonomous Subcarpathian Ruthenia had to struggle alone against imperial revisionism, aggressive propaganda and destructive armed sabotage, were analyzed. Based on the Transcarpathian periodicals, the development of relations between the Carpathian Ukraine and practically the only foreign-policy partner - Germany - is shown in the context of the formation of the Hitler's strategy of the "Eurasian Axis", where the Ukrainian lands had a significant role. Factors of influence on the formation of the new European political reality and the role of the Ukrainian country in it are investigated. When using the press as a key source of historical data, a comprehensive picture of the Central Powers' encroachments and aspirations and their practical intentions in an international crisis is reflected.
\end{abstract}

Keywords: Subcarpathian Rus; Carpathian Ukraine; Rusyns-Ukrainians; Czechoslovak crisis of 1938; Munich Agreement; press; "Ukrainian Piedmont"; common border.

\section{Introduction}

The Munich Agreement of England, France, Germany and Italy created an extremely favorable situation for Germany in Central Europe, which allowed Hitler to have a decisive impact on the fate of the Central European part of the region. Western states that pursued a policy of appeasement of the aggressor, in fact, recognized the priority positions of the Third Reich there and preferred to play the role of an outside observer. As a result of the Munich collusion, Czechoslovakia was significantly weakened because of loss of the territories, important in the militarystrategic and economic terms and about a third of its population, which went mainly to Germany (the Sudetenland). The result of the Second Czechoslovak crisis of 1938 was the division of Czechoslovakia into three parts, each trying to pursue domestic and foreign policies at its discretion without regard to the presence of the single center.

Drawing on a variety of sources, authors set the purpose to reproduce and substantiate the reflection in the periodicals of the attitude of Ukrainians to the policies of the Central Powers and, accordingly, of the European countries to the issue of Subcarpathian Ruthenia in the post-Munich period of 1938 . On the basis of formulating their own general conclusions about the importance of the press as a unique source of resources, the authors of scientific exploration have the opportunity to disclose littleknown pages of political processes in Transcarpathia during the pre-war period. 


\section{Methods}

The methodological basis of scientific exploration is the principle of historical method and scientific objectivity. System-analytical approach allows to consider the sources, nature and specificity of international processes and phenomena of the pre-war period. The interconnections of internal and external factors of development of social and public relations were revealed on the basis of historical and political researches in the world and in Ukraine, which involves the principle of multifactorial analysis. The question of the ideological and social importance of the authority of the policy of concessions and compromises in the context of the formation of concepts of political culture provides the approach of systems of both the integral perception of the object of study and the comprehensive analysis of the relations between its individual elements.

The sources of this scientific research are archival documents held in the State Archives of Zakarpatska Oblast (Transcarpathian region), the Military Historical Archive of the Institute of Military History in Prague, the Hungarian State Archives, the holdings of the Royal Hungarian University Press. Published archival materials are presented by Soviet collections of documents, foreign Ukrainian studies, epistolary and memorial heritage of Yu. Brashchaiko (2009), A. Voloshyn (1995), V. Grenzha-Donskii (1987; 2003) and monographs by researchers of historical science M. Vegesh (2018), V. Hyria (2012), I. Homeniuk (2018), V. Kosyk (1993), L. Trofymovych (2018). Documentary confirmation of the tendencies and peculiarities of the course of crisis events of 1938 are newspaper and journal publications of different ideological directions ("Ukrainske Slovo", "Svoboda", "Nova Svoboda", "Karpatorusky Golos"). Authors emphasize that the interwar press was an important factor of influence on the political culture and national consciousness of Ukrainians in Subcarpathian Ruthenia. Taking into account the democratic endeavors of the Czechoslovak Republic, which included Subcarpathia, the province's press, in addition to informing the population about international events of the time, served as the national voice of freedom, liberation and state formation.

\section{Results}

Following the Munich conference, the Czechoslovak crisis faced internal political conflicts and complex international claims. Due to the socio-political circumstances of 1938, Transcarpatia, which was located in the center of Europe, was inalterably in the field of interests of the various European states. The territory of the region became the scene of a "hybrid war" by the side of neighboring Hungary and Poland. Due to European agreements, not only the Sudeten-German but also the Polish and Hungarian issues were agreed. In spite of whatever efforts the British would make to delineate those issues, they had however to put pressure on the Czechs and call them to address complex of contradictory national issues. In "Ukrainske Slovo" Hitler's demand made to Czechoslovakia on solving its problems with its neighbors was compared with the ultimatum of Austria-Hungary to Serbia in $1914^{1}$. An article about the principle of people's self-determination was published in the "Slovo" on October 15 with reference to the "Völkischer Beobachter" and the "Nazional Zeitung". The main idea of the message of lessons of the past, in particular the national causes of the collapse of the Habsburg empire were mentioned in a memorial heritage:

1 Українське слово (Ukrainske Slovo). Sept.23.1938, page 1.
"The closer ethnographic borders and ethnographic boundaries are and the less mixed nationalities are, what resulted from the Versailles disorder, the sooner peace and calm will come. We the Rusyns-Ukrainians of Subcarpathian Ruthenia will not be tolerated cutting parts from our living body and giving presentations of it to other states!" (Brashchaiko, 2009: 38).

Polish-Hungarian territorial claims on a part of Czechoslovakia, the creation of a common border between the states, which would separate the latter from Romania, its ally in the Little Entente, were of direct relevance to the Subcarpathian public interest. It was the matter of their territorial security and state sovereignty, therefore the opposition to those particular claims was the main task of the Ukrainian regional authorities which relegated projects of the federal arrangement of Subcarpathian lands to the background in October-November 1938. In September, "Nova Svoboda" 2 publishes its items from the position of its self-interest and hypothetical plans of the neighbors,

"...the intentions of the Poles and Hungarians are unjust because history shows that their fate depends on the situation and sometimes international community generously rewarded or crushed them to complete destruction of their statehood".

In October 1938, "Ukrainske slovo" compared the arbitrariness of neighbors with the actions of Hitler's Germany "the surprise at Germany loses its uniqueness when we understand the adequacy of Poland's demands on its neighbor state". At the same time, the despair of the Ukrainian society echoed due to the unwillingness of the great states to solve the Ukrainian issue. Repeatedly, in the press of the Subcarpathia, the Poles of Cieszyn and Ostrava lands were mentioned, to which Munich had given the right to self-determination, and to the Ukrainians of Eastern Galicia it had not:

"If they want to establish an ethnographic principle, then the Poles take 80,000 from the Czechs, so will 8 million Ukrainians be given autonomy? It is best to use the principle "If you give, you give back". The unity of the nation, the integration of the people can be achieved using the principle of ethnic identity. Here we can take the German example" ${ }^{3}$.

The Subcarpathian press informed about the actions of Poland, which, based on German experience and taking the opportunity (in the official versions - "defending the right of peoples to self-determination"), obtained concessions from Czechoslovakia. The Ukrainian press spared no epithets for the Poles: "executioners", "chauvinists", "oppressors", "invaders". Demonstration of Poland's determination was accompanied by power methods when, according to a German scenario, there were some hand grenades and revolvers, forwarded by Polish fighters, found in the Village of Jablunkov near Cieszyn. Having come over to another stage of the relationship with their neighbor, the Poles demanded the annexation of the Cieszyn land in the form of an ultimatum. In early October 1938, elated by the first success, Poland demanded a plebiscite in the districts of Slezská Ostrava and Frýdek, which were mainly inhabited by the Czechs, and laid claims to the Bohumin railway junction. Despite the dramatic historical moment, the Poles proceeded to the implementation of a project of a common border with Hungary ( $\mathrm{Ho}$ meniuk, 2017: 56). "llustrowany Kuryer Codzienny" named

2 Нова свобода (Nova Svoboda). Sept., 24 1938, page 1.

3 Українське слово (Ukrainske Slovo). Oct.08.1938, page 2. 
that demand "an issue of economic importance rather than a rhetorical question".

Bringing forward the ultimatum and further accession of the Czech part of Cieszyn Silesia to Poland was regarded by world community as a proof of coordination of the policies of Poland and Germany. A wave of indignation against the actions of Poland swept through both Czechoslovakia and France. Two weeks later, on October 11, $\mathrm{N}$. Chamberlain in London even had to allege his ignorance of Poland's intentions about an occupation and division of the Czech lands, especially the Subcarpathian Ruthenia, between Poland and Hungary. The French pointed out "... that the steps of Poland were tactless and ignoble and took advantage of the neighbor's difficulties in such a brute way" (Polski dyversiĭ ni dii..., 1998: 28). W. Churchill was rather sharp in his memoirs, noting:

"Nowadays, in 1938, due to such a minor issue as Cieszyn, the Poles have broken up with all their friends in France, England and the USA, who brought them back to a unified national life and whose help they might soon need so much. We have seen how they have hastened to seize their share during the plunder and ruin of Czechoslovakia now that the reflection of the power of Germany has flashed on them" (Ibid: 29).
"Ukrainske Slovo" of September 23 від 23 reference to The Czech "Venkov" stated:

"Out of 34 million people in Poland, 12 million are national minorities, and there is 80 millioned Germany close by, which has recently been quite zealously defending the right of peoples to self-determination. At the time when agreements are a mere scrap of paper, the situation for Poland is even worse than for us".

To confirm the unresolved territorial issues between the Germans and the Poles, "Ukrainske Slovo" of October 6 revealingly described the demarche of the Polish Ambassador, when the issue of returning Danzig and Pomerania was raised at a reception at the French Parliament ${ }^{4}$.

According to publishers of Uzhgorod, Hungary continued a significant violation of the geopolitical balance in Europe by its expansionist actions. The change in the borders of the Czech Socialist Republic resulted in steppingup of the territorial claims and ethnically based revision on the part of Hungary too, which had been seeking to revise the Treaty of Trianon of 1920 throughout the interwar period. Yet on September 22, 1938, the Hungarian Foreign Ministry sent a note to the Czechoslovak government, which demanded the transfer of the Czechoslovak territories, inhabited by the Hungarians, and granting them the right to self-determination.

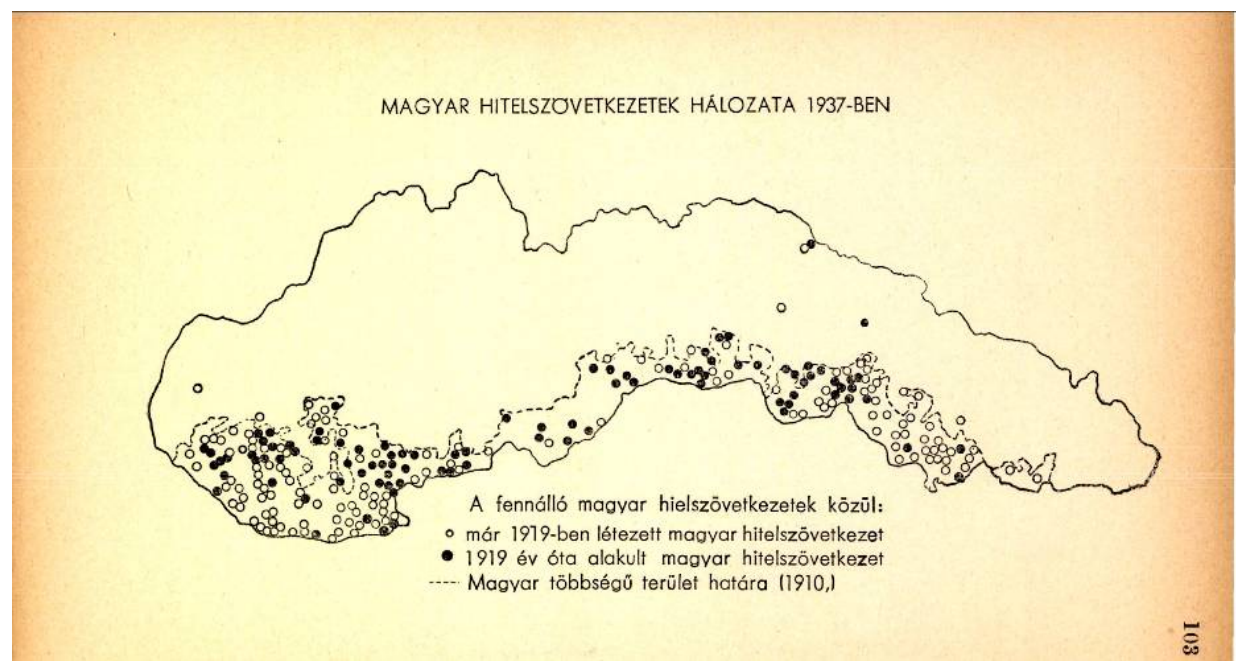

Fig. 1. The map "Twenty years of Hungarians in Upper Hungary 1918-1938"

(A felvidéki magyarság húsz éve 1918-1938 (Budapest. Királyi Magyar Egyetemi Nyomda, 1938).

It should be pointed out that the principle of the right to self-determination was extrapolated by the Hungarians in the territorial and historical rather than ethnic context, and as early as in the spring of 1938 in Transcarpathia there was information about a plebiscite on accession to Hungary. A report by the Berezan Gendarmerie Department informed about a planned Hungarian irredenta ${ }^{6}$ and this was widely spread by the local population.

On October 19, "Ukrainske Slovo" reported an interesting fact about the methods of territorial claims of Hungary, which Slovakia' Prime Minister J. Tiso noted. The argument of the Hungarians for land acquisition was the population census of 1910, during which commissioners recorded a large number of people "under the heading of the Magyar nationality all who could speak Hungarian". J. Tiso, Slovakia's first official, recalled that he was also "Hungarian" according to this census.

\footnotetext{
${ }^{6}$ Державний архів Закарпатської області (далі - ДАЗО України). Fond 2, List 1, File. 325, Page 53 [State archive of Transcarpathian region]
}

Hungary's claims to the Uzhhorod, Mukachevo and Berehovo cities with a minority of the Magyar population, according to Yu. Brashchaiko, contradicted common sense and moral principles. Even in the census of 1910, Jews were on the first place in the population of these cities and the Slavs - on the second. This city had always been considered by Ukrainians-Rusyns to be their original cultural center since 1775, when Empress Maria Theresa passed the castle and Katulska Street to the GreekCatholic bishopric and its bishop A. Bachynskyi (Brashchaiko, 2009: 39).

In its claims Hungary outstepped the senior German friend and, as indicated in the secret encrypted telegram of the Foreign Minister of Hungary K. Kánya to the Ambassador in Prague J. Vetstein on October 3, 1938, it demanded "to transfer 2-3 Czechoslovak border towns with deployment of troops there as a symbolic concession

\footnotetext{
4 Українське слово (Ukrainske Slovo). Oct.06.1938, page 1.

${ }^{5}$ URL: https://hungaricana.hu/hu/search/results/?list=eyJxdWVyeSI6ICJSdXRIbmlhPyogMTkzOCoifQ
} 
well before the approval of the final decision" (Vengriya $i$ Vtoraya Mirovaya voina, 1962: 111).

Allowing for the support of Germany and Italy, which Hungary became closer with in the second half of the 1930 s, the claims indicate the accession of the territories of Slovakia and Subcarpathian Ruthenia. With tacit position of France and Great Britain as well as political games of the fascist states, the government of autonomous Subcarpathian Ruthenia began to fight for its country virtually single-handedly against "Magyar revisionism, imperialism, propaganda, the former conqueror", seeking assistance of the German state.
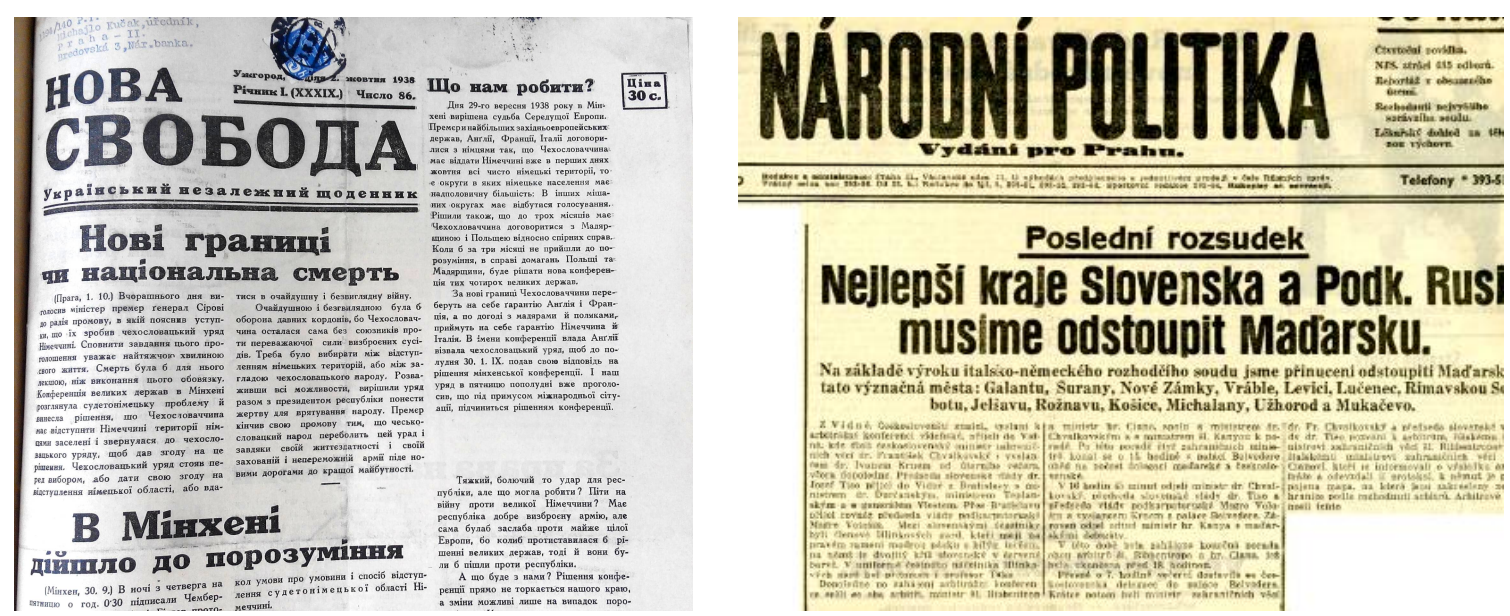

Fig. 2. Title pages of the publications "Narodna Politika" and "Nova Svoboda" with the headlines regarding new borders of Subcarpathian Ruthenia.

On October 16, 1938, at the Great Demonstration Meeting of the Ukrainian People's Council, A. Voloshyn as a representative of the government of its Ukrainophilia current called on all Ukrainian community to declare their unwillingness to join Hungary, "where we were slaves, manure of Magyars" (Ternystyi shliakh do Ukrainy, 2007: 145), through telegraphic appeals to the great states. It was interesting that, showing the statist consciousness, the regional representative body (the First Ukrainian Central People's Council) in a situation of extreme conflict with its southern neighbor, in the Manifesto of October 21, demanded from Prague "to ensure the present borders against Magyaria and to consolidate the whole Zemplynshchyna and Šarišký and Spišské regions with our population to Subcarpathia" (Grenzha-Donskii, 2003: 315-317).

In most European countries, the problem of aggression of neighbors that was felt so strongly by Ukrainians depended on the opinion of leading political players. In publications of October 11-21 the following positions are indicated: Italy stood demonstratively neuter, abandoning itself to the idea that Hungary had to be transferred only ethnic lands without the Hungarian-Polish border in view of reconciliation with the neighbors, because the Versailles system would collapse and no one would guarantee the borders of Czechoslovakia; Yugoslavia and Romania opposed significant attacks by Hungary as the latter understood that it would lose control of the communication to Prague. The Romanian interest is confirmed by a telephone message of the Hungarian Ambassador in Poland, where it is pointed out:

"...the railroad issue is of so great concern to the

Romanians that we need to pin everybody down to the fact as quickly as possible by blasting the railway in Chop, for which Polish and sabotage groups are ready" (Ternystyi shliakh do Ukrainy.., 2007: 63).

In an effort to establish a common border in the Carpathian Mountains, Poland and Hungary tried to destabilize the situation in the region in every possible way by sending a group of combatants from 600 to 2 thousand people across the border to implement acts of sabotage and terror against the units of the Ukrainian National Defense (UNO) on the Czechoslovak borderzone (Hyria, 2012: 107). Their actions coincided with the collapse of the HungarianCzechoslovak talks on October 9-13, 1938 in Komarno. In particular, the Hungarian general staff, through public associations "Levente" and "MOV", organized sabotageterrorist groups "Sobot Chopotok - Free Squads" and "Rongyos gárd - Guard of ragamuffins" (300-500 each) led by M. Kozmi and I. Geyash (Teroarea ..., 1985: 49-52), united with the local "Russkiy Scout", who since the beginning of October 1938 had regularly pestered the south of the region, carrying out repeated attacks on Czech border guards and evacuation convoys, in particular in Borżawa village, Mukachevo, Beregovo, Uzhhorod (Radwańce) cities, destroying rail, telephone and telegraph communications and trying to give the impression of the existence of a powerfully armed pro-Hungurian movement here (Grenzha-Donskii, 1987: 23).

As a result of terrorist operations, combatants were killed or injured. Sabotage detachments of "black shirts", according to some reports, operated under the patronage of Greek Catholic priest S. Fencik, guided by the slogan "drichni Ruthenians all are up in arms because they want to join Hungary"7, and they were aimed to exacerbate the situation in the region. S. Fencik's role in the provokation of the subcarpathian community is confirmed by the October reports of the Hungarian television office. Each reported focus was on the "Rusyn Brothers" in Subcarpathian Ruthenia, which was made a colony by the Czechs, on a favorable economic base that formed over 8 centuries of Ruthenia as part of the Hungarian kingdom. However, nationalist forces indicated that the Hungarians, using the German example, wanted to change the service to God, the calendar, take the land from the peasants, make them labor power, employ for 30,000 unemployed intellectuals awaiting accession to the "mother state" 8

\footnotetext{
${ }^{7}$ Нова свобода (Nova Svoboda). Oct.,18, 1938, page 1.
}

${ }^{8} \mathrm{Ibid}$ : page 2 . 


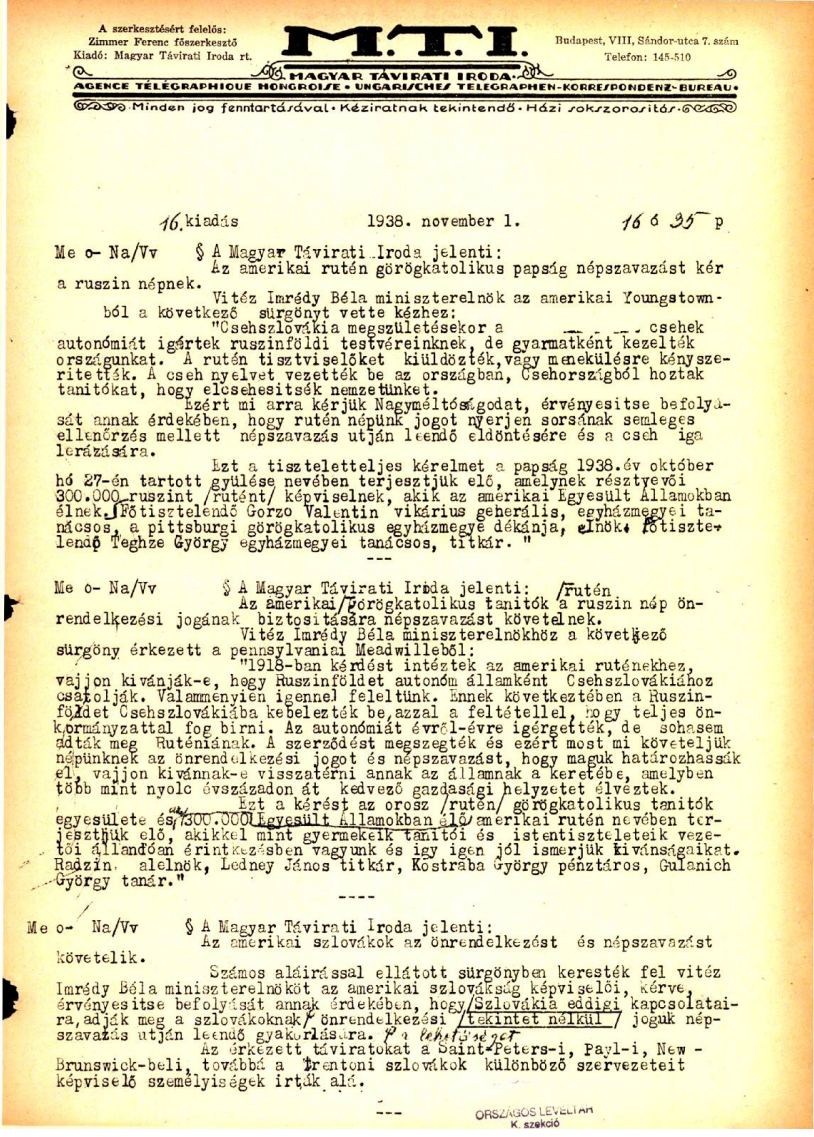

Fig. 3. The message of the office of Hungarian television from 01.11.1938.

(Archivum Magyar Nemzeti Levéltár (MN OL) ${ }^{9}$

The idea of a joint Polish-Hungarian border faced, for a reason, the resistance from Romania which bordered the Subcarpathian Ruthenia in the south-east. In addition to severed relations with Czechoslovakia, the Romanians feared that Hungary's territorial appetites might spread to their country as well. Even J. Beck during his autumn visit to Bucharest failed to change a negative attitude of local leaders to the "great Magyar idea". The latter would prefer that region to be occupied by Poland.

Poland no less than Hungary wanted to establish a common border which would solve the Ukrainian national issue for the Poles (according to some insiders, on October 19 the Foreign Minister of Poland J. Beck in Bucharest offered to transfer to Romania a part of Ruthenia with 40 thousand Romanians). In a conversation with Hitler, he confirmed the Polish side's desire not to raise the Ukrainian issue for peace in the region. In a conversation with Hitler, he confirmed the Polish side's desire not to raise the Ukrainian issue for peace in the region. According to him, the Carpathian Ukraine was inhabited by Rusyns who had nothing common with the Ukrainians (Kosyk, 1993: 64). And in light of the messages from "Karpatorusskiy Golos"10 of the former Foreign Minister V. Paneik, regarding a likely autonomous association of the Subcarpathians and the Galicians with the support of Germany, it is not strange that the Poles, given those circumstances, be-

\footnotetext{
9 URL: https://library.hungaricana.hu/en/view/NapiHirek 193811_1/?query=Rutenia\%3F*\%201938*\&pg=15\&layout=s $\overline{10}$ Карпаторусский Голос. (Karpatorusskii golos). Oct., 13, 1938, page 1.
}

came the greatest lobbyists of Hungarian interests. If we consider the demands for the common border as a precedent, nearly all countries rejected them. Otherwise they faced endless national conflicts within the countries themselves.

It is likely that was precisely why during the Vienna arbitration on November 2, 1939 the Foreign Minister of Germany J. Ribbentrop disagreed with the claims of Poland and Hungary, backed by Italy, to the transfer of Subcarpathian Ruthenia and Slovakia to Hungary. The Foreign Minister of Italy G. Ciano persuaded J. Ribbentrop to award Hungary to the disputed towns and the Vienna arbitration gave it the south of Slovakia and a 12 thousand $\mathrm{km}^{2}$ strip of Subcarpathian Ruthenia with Uzhgorod, Mukachevo and Beregovo. 172 thousand people lived there: 82 thousand Hungarians, 33 thousand Ukrainians, 16.5 thousand Slovaks and Czechs. The above caused a strong protest of both the Ukrainian government of A. Voloshyn (1995: 129) and the American Defense Committee of the Subcarpathian region defense.

The French Ambassador to Berlin, Robert Coulondre (Coulondre R., 1939: 40-41), was of the same opinion. According to him, the Third Reich intended to ensure its decisive role in Central Europe, conquer Czecho-Slovakia and then establish "Great Ukraine" under German control:

"Hitler's entourage thinks about such an operation which would repeat on a larger scale the operation in the Sudetenland: propaganding in Poland, Romania and the USSR for granting independence to Ukraine; diplomatic support and campaign by local volunteer groups at a propitious moment. And Carpathian Ukraine would become a center of the movement"11.

Germany officially took the side of the eastern neighbors in the conflict between Czechoslovakia and Hungary because it had settled the issues with latter, which was reported by "Nova Svoboda" of October 18 with reference to "Berliner Tageblatt". Decentralization, stimulated by Hitler's Germany, which played the role of a leading arbitrator of important political issues in central Europe, led to the disintegration of Czechoslovakia. Germany, "... limiting its claims to an indigenous Sudeten-German region, proved that it considered only such solution of the issue as long-term and stable". The press was already beginning to talk about a full alliance between the Germans and the Czechs, and some publications even suggested that official Germany was interested in creating a Slovak-Ukrainian federal state.

Realizing its interests step by step, Germany did not seek to implement a project of a joint Hungarian-Polish border despite ambivalent actions of Hitler and also the next international conference, which could disrupt his plans. A plebiscite was also not covered by the plans of the Nazi leader since the process would include in electoral lists the Jews of Czechoslovakia, living in the disputed territories. According to "Nova Svoboda"12, the population census of 1910 indicated that they accounted for almost half of the total number of voters, which was contrary to political plans of the NSDAP. On November 27, "Nova Svoboda" reported from Khust that Germany had put forward a note of protest to Poland in respect of the common border with Hungary. The above led to a crisis and the Polish government resigned.

Radio stations in Vienna, Leipzig and Breslau reported "...that the Ukrainians had nothing to worry about, not a

\footnotetext{
11 Нова свобода (Nova Svoboda). Oct., 29, 1938, page 2.

12 Ibid. Oct., 18, 1938, page 1.
} 
single piece of land would fall under Hungarian rule". Seemingly, the Ukrainian issue had to be positively settled because the Czech magazine "Venkov" of October 29 published an article on the importance of creating Carpathian Ukraine as a primary step of international politics and Czechoslovakia survived as a state only thanks to the Ukrainians and their political position. In the same period, there appeared some anti-Czech leaflets, spread by Hungarian and Polish sabotage groups, which had the following messages:

"the state built on lies has been partitioned", "do not believe, you will be SLAVES again in new Czechoslovakia", "the borders of Magyaria are coming nearer to you and you are meeting them halfway"(Ternystyi shliakh do Ukrainy.., 2007: 31).

The irredenta of the pro-Hungarian forces was aggravating the situation in the region every day. Not only calls during meetings and demonstrations, but also other propaganda methods and technologies were used to enhance the effect of the "mother country concern". The proUkrainian Minister of the Regional Government, F. Revai, collected anti-Ukrainian and anti-Czech flyers (leaflets) of October-November in the peak of preparations to the plebiscite, often with threats to government officials (Grenzha-Donskii, 2003: 311-315).

"Brothers! The time for liberation has come! RUSYNS everywhere deprived of a bit to eat! All the fruits of Your fields were taken by Prague! Enough! Throw off the Czech yoke! In a blaze of the crown of St. Stephen you will live in wealth and enjoy religious, economic and political freedom" (Polski dyversiĭ ni dii ..., 1998: 63).

After fruitless negotiations in Komarno on November 2, 1938, with the consent of France and Great Britain, Vienna hosted international arbitration of Germany and Italy, which took a decision to adjust the state border between Czechoslovakia and Hungary with an allowance for the ethnic composition of the population of the neighboring territories. The government of Carpathian Ukraine was represented by Y. Brashchaiko and M. Dolinay in that commission, who were not allowed to participate in the conference. On November 5 , Ukrainian periodicals came out with the main message: "with a sore heart we advise you as follows: the representatives were forced to accept the conditions because we have no strength to fight with world powers"13.

However, Hungary was not satisfied with the connection of the southern territories to its territory by the international arbitrament. On November 20,1938, the full occupation of the Carpathian Ukraine was planned. From the reports of the Hungarian ambassador in Warsaw to the Minister of Foreign Affairs Kálmán de Kánya it is known that the general staffs of Hungary and Poland developed a formula of the statement that "the Rusyn population asked Hungarian and Polish troops to enter into the Rusyn region at the same time". This commentary was prepared to explain own annexationist actions to the world community (Vengriia i Vtoraia Mirovaia voina, 1962: 132-135). Only the sharp notes of Germany and Italy on November 21, 1938 forced the Hungarians to cancel the dangerous plan.

The regional authorities of Subcarpathian Ruthenia, which was granted autonomy under complete pressure, chose a policy of search and support of an ally. In addition to official Prague, the Ukrainians were supported by official German circles. The positive "cordial" attitude of Ukrainians to the Germans is the cross-cutting theme of entire media

13 Нова свобода (Nova Svoboda). Nov., 04, 1938, page 1. space of the Carpathian periodicals. As a result of $\mathrm{Y}$. Bachinsky's meetings with J. Ribbentrop on October 19 and those of A. Voloshin with the Editor-in-Chief of "Völkischer Beobachter" K. Bigal on October 21, there were numerous promises of support given. K. Bigal personally came to Subcarpathia for negotiations about the protection of the interests of the Germans in Mukachevo and Svaliava. It was decided to maintain friendly relations and develop diplomatic relations. Unfortunately, these contacts were of a private nature, violated current Czech law and prompted the slim hopes of the Transcarpathian movement's leaders to create the "Ukrainian Piedmont"14.

The press reports on the first positive contacts with German organizations and the steps of official Berlin rather often and systematically. The formation of the pro-German foreign policy orientation is explained by the need for external support and strong opposition to encroachment of Budapest and Warsaw in relation to seizure of the territory of the region. The Ukrainian issue in the context of the Czechoslovak crisis was covered not only in periodicals of Subcarpathian Ruthenia but also in articles of the German periodicals "Völkischer Beobachter", "Frankfurter Zeitung", "Kölnischen Zeitung" and "Essener Nazional Zeitung", published on 24-25 October, which dealt with autonomy of Carpathian Ukraine, reunification with Hungary etc.

The relations of Carpathian Ukraine with Germany as with practically the only foreign-policy partner developed perspectively to form a cooperation strategy and influenced the state-building idea, as was announced by official government documents. In "Nova Svoboda", with reference to the Warsaw diary "ABZ", two directions of German foreign policy were revealed. The first direction was represented by the ideologist $A$. Rosenberg. He proposed a plan for the creation of Piedmont from Subcarpathian Ruthenia, and for the rest of the Ukrainian lands "liberation from the Hungarians and Bolshevik captivity" was proposed. This concept was called "Promethean". Another position was described by R. Hess with the support of the Hungarians, because the pro-Ukrainian policy of Germany would have encountered with Great Britain and would have counteracted its movement in the East of Europe under the slogan "if we did not return the colonies, we should give our free hand in the East of the country"15.

According to its insiders, "Ukrainske Slovo" of September 25, describing the worthlessness of the AngloFrench agreements, alluded to Hitler's plans to seize the lands up to the Black Sea. French "Paris-Midi" of October 20 called the Subcarpathian region a key to Eastern Europe and Germany did not want Ruthenia to go over to some other state. Political subordination of the Ruthenia region to Germany would open the way to Romanian oil and bread. "Excelsior" and Warsaw "Dziennik" pointed out that Romania, Ukraine and the Black Sea coast were stages of German expansion to oil sources. Ruthenia was considered as a wheel of the "Eurasian axis". Germany aimed to reach Mosul and that conflicted with the sphere of influence of Great Britain, which would lead to a conflict of yesterday's allies.

The press informed community about Germany's plans for the realization of Ukrainian issue, especially territorial issue. Behind an information veil, Germany covered up the true goals of Hitler's policy in Europe. On the other hand, the idea of Hitler's campaign against Bolshevism perfectly coincided with Western European expectations, phobias and aspirations to prevent the unrestrained

\footnotetext{
14 Нова свобода (Nova Svoboda). Oct.,23, 1938, page 1. 15 Ibid: page 2.
} 
aggression of the Third Reich to the east. In respect of the Carpathian Ukrainian issue, Berlin undertook a complex diplomatic game, trying to subordinate to its influence those states which interests were directly affected by the existence of Ukrainian autonomy in the Subcarpathian region. The Ukrainian issue therefore became a mere instrument in the hands of the Third Reich which did not intent to solve it, using Ukrainian national political forces in its strategic plans.

\section{Conclusions}

A clear orientation in the geopolitical situation in Europe, in the face of the growing aggressive policies of Poland and Hungary under the silent position of France and Great Britain, as well as political games of the fascist states, helped the Ukrainians to take consistent steps in seeking independence in the most difficult conditions of geopolitical isolation and ethno-national tension, when the government of autonomous Subcarpathian Ruthenia did not give up hope for affirmation and preservation of the national form of social life, even being alone with the hostile environment, which rushed to the active contacts of people of Galicia and Subcarpathia.

The cohesion on the main idea, which runs through the entire media space of that period - resolving the national issue and establishing statehood - allows to point out the high political culture of the population of the region in the conditions of destabilization of the political situation, intensification of the aggressive activity of neighboring Hungary and Poland, armed provocations and the ideological pressures.

Reflecting public attitudes, the subcarpathian press with optimistic hope supported the idea of the Promethean conception of "Ukrainian Piedmont" proposed by A. Rosenberg, and, after all, was drawn into a major political game, caught in the epicenter of the conflict of interests of the great states, for which the question of national self-determination became illusive.

Public opinion, formed by the press, despite the positive connotations of "peoples' right to self-determination" as a compromise result of the Munich collusion, tracked a diplomatic game of world states that could not agree because of their own ambitions, and for which, unfortunately, Subcarpathian Ruthenia became as currency.

\section{REFERENCES}

Brashchaiko, Yu. (2009). "Shcho ya vydiv na Zakarpatti..." ["What I saw in Transcarpathia..."]. Uzhhorod: Lyra (In Ukrainian).

Vegesh, M. (2018). Derzhavno-pravovi osnovy isnuvannia Karpato-Ukrainskoi derzhavy (1938-1939). Naukovyi visnyk Uzhhorodskogo nazionalnogo universytetu. Seria: Mizhnarodni vidnosyny. Issue.3. (In Ukrainian).

Vengriia $i$ Vtoraia Mirovaia voina: sekretnye diplomaticheskie dokumenty istorii kanuna I perioda voiny. (1962). Moskva: Politizdat. (In Russian).

Voloshyn, A. (1995). Tvory. Uzhhorod: Grazhda. (In Ukrainian).

Hyria, V. (2012). Ugorska iredenta v mizhvoiennomu Zakarpatti ("ugorskyi factor" u suspilno-politychnomu zhytti). Uzhhorod: Vydavnytstvo "Karpaty". (In Ukrainian).

Homeniuk, I. (2017). Provisnyky Druhoi svitovoi. Prykordonni konflikty $v$ Tsentralno-Skhidnii Yevropi. Vid rozpadu imperii do Hliaivitskoi provokatsii. [Proponents of the Second World. Border conflicts in Central and Eastern Europe. From the collapse of the empires to the Gleyevitz provocation]. Khakriv: CSD (In Ukrainian)

Grenzha-Donskii, V. (1987). Shchastia I gore Karpatskoi Ukrainy: Shchodennyk. Tvory. T. VIII. Washington: Vydannia Karpatskogo Soiuzu. Uzhhorod: Zakarpattia. (In Ukrainian).
Grenzha-Donskii, V. (2003). la tezh ukrainets. (In Ukrainian).

Kosyk, V. (1993). Ukraina i Nimechchyna u Drugĩ svitoviĩ viĩ ni. Paris; New-York; Lviv: Naykove tovarystvo imeni T. Shevchenka u Lvovi; Ukrainoznavcha biblioteka NTSh. (In Ukrainian)

Polski dyversĩ ni dii v Zakarpatskii Rusi v svitli dokumentiv viddilu Il Genshtabu Viiska Polskogo. (1998). Warshawa. (In Ukrainian).

Ternystyi shliakh do Ukrainy: Zbirnyk arkhivnykh dokumentiv $i$ materialiv. Zakarpattia v yevropeiskii politytsi. 1918 - 1919, 1938 - 1939, 1944 - 1946 rr. XX st. (2007) [The Stinging Way to Ukraine: A Collection of Archival Documents and Materials. Transcarpathia in European politics. 1918 - 1919, 1938 1939, 1944 - 1946. XX century]. Uzhhorod: VAT "Vydavnyztvo Zakarpattya" (In Ukrainian).

Trofymovych, V., Trofymovych, L. (2018). Pytannia Pidkarpatskoi Rusi u zovnishniopolitychnykh rozrachunkach Polshchi (zhovten 1938 - berezen 1939 r.). Rusin. № 52. DOI: https://doi.org/ 10.17223/18572685/52/21 (In Ukrainian).

Coulondre, R. (1939). French Ambassador in Berlin, to M. Georges Bonnet, Minister for Foreign Affairs. Berlin, December 15, 1938. The French Yellow Book. Paris (In English).

Teroarea horthysto-fascista in nord-vestul Transilvaniei (19401944) (1985). Bucuresti (In Rumanian). Retrieved from: https:/ /www.slideshare.net/FrescatiStory/teroarea-horthystofascista-in-nordvestul-transilvaniei-1940-1944.

\section{LIST OF REFERENCES LINK}

Бращайко Ю. М. "Що я видів на Закарпаттю...": Спогади. Ужгород: Ліра, 2009.

Вегеш М. М. Державно-правові основи існування КарпатоУкраїнської держави (1938-1939). Науковий вісник Ужгородського національного університету. Серія: Міжнародні відносини. 2018. Вип. 3.

Венгрия и Вторая мировая война: секретные дипломатические документы истории кануна и периода войны. Москва: Политиздат, 1962.

Волошин А. Твори. Ужгород: Ґражда, 1995.

Гиря В. Угорська іредента в міжвоєнному Закарпатті ("угорський фрактор" у суспільно-політичному житті). Ужгород: Видавництво "Карпати", 2012.

Гоменюк І. Провісники Другої світової. Прикордонні конфолікти в Центрально-Східній Європі. Від розпаду імперій до Гляйвіцької провокації. Хакрів: Клуб сімейного дозвілля, 2017.

Гренджа-Донський В. Щастя і горе Карпатської України: Щоденник. Твори. T. VIII. Вашінгтон: Видання Карпатського Союзу, 1987.

Гренджа-Донський В. Я теж українець. Ужгород. Закарпаття, 2003.

Косик В. М. Україна і Німеччина у Другій світовій війні. Париж; Нью-Йорк; Львів: Наукове товариство імені Т. Шевченка у Львові; Українознавча бібліотека НТШ, 1993.

Польські диверсійні дії в Закарпатській Русі в світлі документів відділу II Генштабу Війська Польського. Варшава, 1998.

Тернистий шлях до України: Збірник архівних документів і матеріалів "Закарпаття в європейській політиці 1918-1919, 1938-1939, 1944-1946 рр." / Упорядкування, передмова та покажчик О. Д. Довганича та О. М. Корсуна. Ужгород: ВАТ "Видавництво"Закарпаття", 2007.

Трофимович В. В., Трофимович Л. В. Питання Підкарпатської Русі у зовнішньополітичних розрахунках Польщі (жовтень 1938-березень 1939 р.). Русин. 2018. № 52. DOI: https:// doi.org/10.17223/18572685/52/21

Coulondre R. French Ambassador in Berlin, to M. Georges Bonnet, Minister for Foreign Affairs. Berlin, December 15, 1938. The French Yellow Book. Paris, 1939. pp. 40-41.

Teroarea hortisto-fascista in nord-vestul Transievaniei. Bucuresti, 1985. URL: https://www.slideshare.net/FrescatiStory/teroarea-horthystofascista-in-nordvestul-transilvaniei-1940-1944. 
Тетяна Купрій,

Київський університет імені Бориса Грінченка (м. Київ, Україна)

e-mail: t.kuprii@kubg.edu.ua, ORCID 0000-0002-7305-5411

Лідія Тиміш,

Дрогобиџький державний педагогічний університет імені Івана Франка (м. Дрогобич, Україна) e-mail: lidatymish21@gmail.com,ORCID 0000-0002-2142-8917

Леонід Панасюк,

Київський університет імені Бориса Грінченка (м. Київ, Украӥна)

e-mail: panlev@ukr.net, ORCID 0000-0003-4216-8808

\section{ПІДКАРПАТСЬКА РУСЬ В УМОВАХ ПЕРЕДВОЄННОї \\ МІЖНАРОДНОї КРИЗИ 1938 РОКУ ТА ТЕРИТОРІАЛЬНИХ ЗАЗІХАНЬ СУСІДНІХ ДЕРЖАВ (ЗА МАТЕРІАЛАМИ РЕГІОНАЛЬНОїПРЕСИ)}

Крізь призму підкарпатської преси першої третини XX ст. висвітлено трагічний період становлення української державності напередодні II Світової війни, перебіг боротьби за вільний розвиток української нації на території Підкарпатської Русі внаслідок Мюнхенської угоди й небезпечної політичної гри Англії, Франції, Німеччини та Італії, а також Польщі та Угорщини, в епіцентрі амбіцій яких опинилося Закарпаття. Подальшого висвітлення отримали питання боротьби українців Закарпаття за втілення "права народів на самовизначення" в процесі силового формування спільного польсько-угорського кордону після Другої Чехословацької кризи 1938 р., що дала початок фактичному поділові Чехословаччини 3 одного боку, та активізації національних прагнень українців 3 іншого. Проаналізовано геополітичні аспекти гри центральноєвропейських держав, а також Польщі та Угорщини в процесі "перекроювання Європи", міжнародні особливості політики умиротворення агресора 1938 р. як процесу поступок та втрат, у яких закарпатські землі залишалися розмінною монетою, а уряд автономної Підкарпатської Русі був змушений самотужки боротися проти імперського ревізіонізму, агресивної пропаганди та руйнівних збройних диверсій. Спираючись на закарпатську періодику, автори показали розвиток взаємин між Карпатською Україною та практично єдиним зовнішньополітичним партнером - Німеччиною - в контексті формування гітлерівської стратегії "Євразійської осі", де українським землям відводилась значна роль. Досліджено чинники впливу на формування нової європейської політичної реальності й ролі в ній українського краю. При використанні преси як ключового джерела історичних даних відображено цілісну картину зазіхань і прагнень центральноєвропейських держав та їх практичні наміри в умовах міжнародної кризи.

Ключові слова: Підкарпатська Русь; Карпатська Україна; українці-русини; Чехословацька криза 1938 р.; Мюнхенський договір; преса; "Український П'ємонт"; спільний кордон.

(C) Tetiana Kuprii, Lidiia Tymish, Leonid Panasiuk

Надійшла до редакції: 17.10.2019

Прийнята до друку: 04.11.2019 